\title{
ST. EPHRAIM THE SYRIAN'S THOUGHT AND IMAGERY AS AN INSPIRATION TO BYZANTINE ARTISTS ${ }^{\dagger}$
}

\author{
ZAGA GAVRILOVIC \\ INSTITUTE FOR ADVANCED RESEARCH IN THE HUMANITIES \\ THE UNIVERSITY OF BIRMINGHAM \\ UNITED KINGDOM
}

[1] For students of Byzantine art, St. Ephraim the Syrian is linked with the iconography of the Last Judgment. This paper gives an account of the previous research concerning his part in the development of that theme, although it is usually accepted that all previous conclusions were in fact based on pseudo-Ephraimic writings. However, in this article, a genuine text by St. Ephraim, which confirms that link, is introduced into the discussion. It is pointed out that, thanks to a great number of modern studies and the wider availability of St. Ephraim's works, it is becoming possible to establish a more general connection between his thought and imagery and the art of the Byzantine world. This article includes a brief survey of the representations of St. Ephraim in Byzantine portraiture and of the iconography of his death and funeral.

One of the earliest preserved representations of St. Ephraim the Syrian in Byzantine art is on a small $10^{\text {th }}$ century icon at St. Catherine's Monastery, Mount Sinai. ${ }^{1}$ The icon is divided into two

t The General Editor acknowledges the assistance received from Eileen Wilson in scanning the images from slides.

1 K. Weitzmann, "The Mandylion and Constantine Porphyrogenetos," CahArch XI (1960): 163-184. A photograph in colour, in id., The 
registers. The upper part illustrates the legend of Abgar, the king of Edessa. On the left, sitting on a throne, is the apostle Thaddaeus, one of the Seventy, who, according to tradition, brought Christianity to Edessa. He is turning towards King Abgar, also enthroned, on the right. The king is holding on his lap the miraculous image of Christ on a cloth, the Mandylion, which has just been brought to him by a messenger. The lower zone is reserved for four standing saints: St. Paul of Thebes, St. Antony the Abbot, St. Basil of Caesarea and St. Ephraim. Wearing episcopal dress, St. Basil is holding a large book, while the two Desert Fathers, as well as St. Ephraim, wear monastic clothes: a light brown tunic and a dark brown cloak. However, St. Paul and St. Antony also wear the analabon whose long frontal piece shows under the mantle, thus denoting their megaloschema monastic status. ${ }^{2}$ In addition, St. Antony has his head covered with a koukoulion. Like St. Basil, St. Ephraim holds a large book. ${ }^{3}$ It is perhaps a coincidence, but it is worth observing that these four saints are all commemorated in the month of January. ${ }^{4}$

It is easy to explain the presence of St. Ephraim on an icon whose main subject concerns Edessa, the city to which he came around the year 363, after being forced to leave his native Nisibis. St. Ephraim spent the last years of his life in Edessa, teaching, writing, taking an active interest in the issues of faith and a resolute stand against heresies. He died in 373. The fact that on the Sinai icon he is depicted next to St. Basil recalls his legendary association

Monastery of Saint Catherine at Mount Sinai: The Icons, vol. 1 (Princeton, 1976) 94-98, Pl. XXXVI.

2 On distinctions in monastic dress, see The Oxford Dictionary of Byzantium (1991), s.v. schema.

${ }^{3}$ It should be noted that St. Ephraim usually wears monastic garb, although he was not a monk. On St. Ephraim's asceticism, which was typical of the earlier Syrian tradition of the consecrated life, or "protomonasticism," and the literary sources, which from the $5^{\text {th }}$ century onwards confuse that tradition with Egyptian monasticism and portray St. Ephraim as a monk, see S. Brock, The Luminous Eye: The spiritual world vision of St. Ephrem the Syrian (Cistercian Studies 124; Kalamazoo, 1992²), 13141; id., St. Ephrem the Syrian, Hymns on Paradise (Crestwood/New York: St Vladimir's Seminary Press, 1990) 25-33. R. Murray, "Ephrem Syrus, Saint," in A Catholic Dictionary of Theology (1967).

${ }^{4}$ St. Basil, $1^{\text {st }}$ January; St. Paul of Thebes, 15th January; St. Antony, $17^{\text {th }}$ January; St. Ephraim the Syrian, 28 ${ }^{\text {th }}$ January. 
with the Cappadocian father, first mentioned by the $5^{\text {th }}$ century church historian Sozomenos. ${ }^{5}$ The unhistorical meeting of the two was represented on a fresco (now destroyed) at the Tokali New Church in Göreme, Cappadocia (10 ${ }^{\text {th }}$ century), where it was part of a cycle of the Life of St. Basil. ${ }^{6}$

The choice of St. Paul of Thebes and St. Antony in company with St. Basil and St. Ephraim on the Sinai icon, is a clear indication of St. Ephraim's high rank amongst the teachers of the ascetic life as practised in monasteries such as St Catherine's (for which the icon was presumably prepared. ${ }^{7}$

A fine miniature illustrating St. Ephraim's death and funeral heads the one-page lection in the Menologion of Basil II (cod. Vat. gr. 1613), dating from the end of the $10^{\text {th }}$ century. The scene is a simple event taking place in a stony landscape: the saint, whose feet are bare, is lying on his mat. One monk officiates, waving a thurible, while two other monks stand in prayer. ${ }^{8}$

From the $11^{\text {th }}$ century onwards, the extant representations of St. Ephraim are more frequent, especially in monumental churchdecoration, where he usually appears as an individual figure, amongst other holy monks. ${ }^{9}$ A different example occurs in an

${ }^{5}$ S. Brock, St. Ephrem the Syrian: Hymns on Paradise (1990) 21.

6 G. de Jerphanion, Une nouvelle province de l'art Byzantin: Les églises rupestres de Cappadoce I/ 2 (Paris, 1932) 363-4. According to de Jerphanion, the frescoes, with the inscriptions, followed the episodes of St. Basil's Life by Pseudo-Amphilochios of Iconion.

${ }^{7}$ For Weitzmann (see n. 2), the presence of the three holy monks and St. Basil indicates that the icon was intended for a monastery, possibly Sinai itself. As the icon consists of two smaller panels inserted in a frame, he supposed that they originally formed the two side-panels of a triptych whose middle piece is missing. The central panel would have had a larger representation of the Mandylion, and of some other saints in the lower register. This means that the series of monastic teachers would have included perhaps four others between St. Paul of Thebes and St. Basil of Caesarea.

${ }^{8}$ Il Menologio di Basilio II (Turin, 1907), 354.

9 On representations of monks in monumental art, including St. Ephraim, see S. Tomekovic, "Le 'portrait' dans l'art byzantin: exemple d'effigies de moines du Ménologe de Basile II à Decani," in V. J. Djuric (ed.), Decani et l'art byzantin au milieu du XIV ime siècle (Belgrade, 1989) 121136; ead., "Ermitage de Paphos: décors peints pour Néophyte le Reclus," 
illustrated Psalter copied and illuminated in 1066 at the Stoudios monastery in Constantinople. ${ }^{10}$ On the margin of fol. 97, St. Ephraim is represented standing with his arms raised in prayer, looking up towards Christ who is blessing him. As usual, St. Ephraim wears a monastic habit, this time with the analabon of the megaloschema. The miniature accompanies the verse from Ps. 74(75): 2: "We will give thanks to thee, O God, we will give thanks and call upon thy name: I will declare all thy wonderful works." The Psalm continues by warning the sinners that "God is the judge: he puts down one and raises up another." In view of the general character of the illustrations in the London Psalter, which interpret the meaning of the text in a subtle and often symbolic way, ${ }^{11}$ the inclusion of St. Ephraim in this place may be understood as significant. It allows us to grasp the manner in which the beauty of St. Ephraim's poetry and his spirituality were appreciated by the $11^{\text {th }}$ century artists and their patrons.

In later periods, as on a fresco in a small Serbian church at Psacha (ca. 1360), St. Ephraim was almost invariably given a serious, even an austere expression (Fig. 1). ${ }^{12}$ At the same time, one can recognize in this face a theologian and an inspired poet, of whose talent the painter was well aware. This artistic interpretation of St. Ephraim's personality seems to correspond perfectly to the meaning of the hymns sung on his feast: they praise St. Ephraim's teaching and refer to him as "The Harp of the Holy Spirit." The artist who painted this portrait must also have had in mind the profound sense of St. Ephraim's soul-searching prayer, which is pronounced with prostrations at the weekday-offices during Lent. ${ }^{13}$

In art-historical studies St. Ephraim is mostly associated with the representations which interpret the belief in Christ's Second Coming and his Judgment. Although St. Ephraim's writing is

in C. Jolivet-Lévy, M. Kaplan, J.-P. Sodini (eds.), Les saints et leur sanctuaires à Byzance (Paris, 1993) 151-71.

10 S. Der Nersessian, "L'Illustration des psautiers grecs du Moyen Âge II. Londres Add.19.352," Bibliothèque des Cabiers Archéologiques (Paris, 1970) 40, Fig. 158.

11 Der Nersessian, "L'Illustration des psautiers grecs," $77 \mathrm{f}$.

12 On the church of St. Nicholas, Psacha, see V.J. Djuric, Vizantijske freske $u$ Jugoslaviji (Belgrade, 1975) 75-6 and 216-7.

13 The Lenten Triodion, tr. Mother Mary and Archimandrite Kallistos Ware (London/Boston, 1977) 48 and 69-70. 
nowadays well known and its importance duly acknowledged, his name is still only sporadically mentioned in connection with any other theme of Byzantine iconography, or with Byzantine art in general: above all, he is still regarded as one of the main sources of inspiration for artistic descriptions of the dramatic events which are expected to happen at the end of days. ${ }^{14}$

In addition to presenting St. Ephraim as he is still best known in art-historical circles, my aim in this paper is to point out some other instances which suggest that his thought, his views on the position of humanity in relation to God, and his abundant and original imagery, may have played a considerable role in the creation of other iconographic themes, influencing in some cases even the stylistic manner in which they were executed. ${ }^{15}$

In 1844, writing on the representations of the Last Judgment on the stained-glass windows of the cathedral at Bourges, two French historians, Cahier and Martin, were apparently the first to connect some of the texts from the corpus attributed to St. Ephraim with the scenes which they were studying. ${ }^{16}$

In 1945 the French Byzantinist Gabriel Millet published a study of an ecclesiastic vestment preserved in the Vatican treasury and traditionally known as the "Dalmatic of Charlemagne." This magnificent dalmatic, or sakekos, embroidered in gold on blue silk, is in fact a Byzantine work, dating from the $14^{\text {th }}$ century. ${ }^{17}$ On one of

14 A summary of the bibliography concerning the Last Judgment in Byzantine art, with a particular reference to the question of St. Ephraim's influence, is included in a recent study by A. Davidov-Temerinski, "Cycle of the Last Judgment" (in Serbian with an English summary), in V.J. Djuric (ed.), Mural Paintings of the monastery of Decani (Belgrade, 1995) 192-211 (see below, notes 23 and 24).

15 My own information on St. Ephraim's writing has been gleaned from a selection of the otherwise impressive number of modern studies which have opened up an entirely new field of research. For the bibliography, see especially S. Brock's works, quoted in note 2. I wish to thank Dr. Andrew Palmer for letting me see his translations of St. Ephraim's Hymns of Faith which he is preparing for publication.

16 The same connection was made by G. Voss, Das Jüngste Gericht in der bildenden Kunst des Mittelalters (Leipzig, 1883). See D. HemmerdingerIliadou, "Les données archéologiques dans la version grecque des sermons de saint Éphrem le Syrien," CahArch XIII (1962): 29-37.

${ }^{17}$ G. Millet, La dalmatique du Vatican. Les Élus: images et croyances (Paris 1945). The photographs of the dalmatic were published in id., Broderies 
its sides, within a large circle, is represented Christ Emmanuel in a mandorla of light, sitting on a rainbow, with his feet resting on fiery wheels, as in the vision of the prophet Ezekiel. The four beasts, understood as symbols of the four evangelists, are placed around Him. The inscription in Greek, on each side of Christ's head, reads "Jesus Christ, the Resurrection and the Life" (John 11: 25). Christ is blessing with his right hand and is holding a book of the Gospels in his left, open at the words from the Gospel of St. Matthew, 25:34: "Come ye blessed of my Father, inherit the kingdom prepared for you from the foundation of the world." Christ's mandorla is surmounted by a Cross, with lance and nails. The blue background of the sky is studded with gold stars and the Cross is flanked by the sun and the moon. The Mother of God and St. John the Baptist are in prayer on either side of Christ, with archangels and angels behind them. In the lower portion of the circle, two groups of the just, men and women, are converging towards the centre. In the lower left corner, outside the circle, is represented "Abraham's bosom" (Luke 16: 22): Abraham with Lazarus on his lap and a few other souls standing at his side. In the right corner is the Good Thief, holding a large Cross.

This composition, which represents an abbreviated version or the first part of the event, was Millet's starting point in his research concerning the theme of the Last Judgment in Byzantine art. According to the preserved examples, its main characteristics were fully established by the $11^{\text {th }}$ century. ${ }^{18}$ Based on Scripture (Matthew 16:27; 24:30), the Book of Revelation (chapters 4 and 20), the Psalms and the Book of Daniel (chapter 7), its iconography was enriched from the writings of later Christian authors. Amongst these Gabriel Millet recognized in particular St. Ephraim the Syrian. He considered sermons in Greek and Syriac published under St. Ephraim's name by J.S. and S.E. Assemani, P.B. Mobarek and T.J. Lamy, especially those on The Second Coming, De magis and de fine extremo. ${ }^{19}$

religieuses de style byzantin (Paris, 1945), Pl. CXXXV_CLI. See also E. Piltz, “Trois sakkoi byzantins," Acta Upsaliensia N.S. 17 (1976): figs. 5-7, 9-10.

18 B. Brenk, "Die Anfänge der byzantinischen Weltgerichtsdarstellung," BZ 57/1 (1964): 106-26; id., "Tradition und Neuerung in der christlichen Kunst des ersten Jahrtausends," Studien zur Geschichte des Weltgerichtsbildes (Wien, 1966).

${ }^{19}$ Millet, La dalmatique, 14-8. 
[13] On the basis of her research concerning the authenticity of the Greek and Slavonic translations of St. Ephraim's writings, Democratia Hemmerdinger-Iliadou announced a monograph on the Last Judgment. Unfortunately, she died before completing that study. Sermons which went under St. Ephraim's name and were used by Gabriel Millet, are now known not to be genuine, although Iliadou herself admitted that the whole situation, at least for works of St. Ephraim in Greek and Slavonic, was still fluid. ${ }^{20}$

In the mean time, a very important text containing references to the Last Judgment has been brought to light. ${ }^{21}$ It is a genuine Ephraim, a text of great beauty, whose profound thought can contribute a great deal to the study of the subject, textually as well as art-historically. To my knowledge, it has not yet been used by art historians.

[15] As is well known, in his research on Byzantine iconography, Gabriel Millet relied to a great extent on the monuments of medieval Serbia, which he explored during his field-work in the Balkans, before and after the First World War. ${ }^{22}$ He soon became aware of the closeness of the Serbian wall-paintings to their Byzantine models, so he made good use of the great wealth of themes he found in them. The relatively good state of preservation of some of those frescoes facilitated his task. In his study of the Last Judgment, with the Vatican dalmatic and the writing of St. Ephraim_or pseudo-Ephraim_as a starting-point, he took into consideration most particularly the Last Judgment in the Serbian church of the Pantokrator, at the monastery of Dechani, in the region of Metohija-Kosovo, built and decorated between 1327 and 1348 (Fig. 2). ${ }^{23}$

${ }^{20}$ D. Hemmerdinger-Iliadou, "Les données archéologiques;" ead., in Dictionnaire de Spiritualité 4 (1960): 800-19; ead., "L'Éphrem grec et la littérature slave," Actes du XII Congrès international d'études byzantines (Ochrid, 1961) II (Beoograd, 1964) 343-6.

${ }^{21}$ S. Brock, "Ephrem's Letter to Publius," Le Muséon. Revue d'Études orientales 89 (1976): 261-305.

22 See A. Frolow's Introduction to G. Millet, La Peinture du Moyen Âge en Yougoslavie, I (Paris, 1954) V-VII; D. Couson, Catalogue des documents photographiques originaux du fonds Gabriel Millet: Monuments mediévaux de Yougoslavie. Missions 1906-1935 (Louvain/Paris, 1988).

23 The church was founded by King Stefan Uroš III (1321-31). The fresco decor was completed during the reign of his son, King and later 
The huge composition at Dechani starts in the groin-vault above the west bay of the naos and is then deployed in the upper zones of the west wall, as well as on some parts of the adjoining walls and pillars. The inscriptions are in Old Serbian (Fig. 3). ${ }^{24}$

The north, east and south segments of the groin-vault are reserved for monumental figures of angels who are blowing trumpets, carrying large candlesticks with candles lit (Fig. 4), or rolling up the heavenly vault, which is like a large sheet of parchment, studded with golden stars (Fig. 5). More stars and the personifications of the Sun and of the Moon are depicted in the background (Figs. 4 and 5). ${ }^{25}$

One particularity distinguishes the Last Judgment at Dechani from so many of the usual compositions structured around Christ of a mature age, enthroned and identified as a Judge. It is the representation of the event in two stages: the Coming of Christ in glory, followed by the solemn scene of his Judgment. Placed in the west segment of the groin-vault, the adolescent Christ Emmanuel on a throne- a representation akin to the one on the Vatican dalmatic - is being carried down by two angels. Dressed in a yellow-ochre tunic originally covered with gold leaf (there are still traces of gold on many of the frescoes at Dechani), He blesses with both hands (Figs. 6 and 7). Just below the enthroned Emmanuel, there is a representation of the hetoimasia, or the prepared throne, mentioned in the Psalms and in the Book of the Revelation of St. John. It is a regular feature in the iconography of the Last Judgment. In Dechani, it is flanked by groups of angels and by the

Emperor, Stefan Uroš IV Dušan (1331-46; 1346-50). There is an extensive bibliography on Dechani. See especially V. Petkovic and Dj. Boškovic, Manastir Decani, 2 vols. (Belgrade, 1941); V.J. Djuric (ed.), Decani et l'art byzantin au milieu du XIV ime siècle (Belgrade, 1989); V.J. Djuric (ed.), Mural painting of monastery of Decani (Belgrade, 1995). This last is a collection of studies by 13 scholars (with English summaries), published after a new investigation of wall-paintings (between 1988-90). It contains architectural drawings of the programme's setting, a complete list of subjects and a great number of photographs.

24 See the excellent article by A. Davidov-Temerinski, in the above publication, already quoted in n. 14, whom I thank for her kindness and help in obtaining some of the photographs.

${ }^{25} \mathrm{~V}$. Kepetzi, "Quelques remarques sur le motif de l'enroulement du ciel dans l'iconographie byzantine du Jugement Dernier," DChAE IV/17 (1994): 99-112. 
Virgin Mary and St. John the Baptist. The inscription reads: "The Second Coming." Immediately below are Adam and Eve, prostrate and in prayer. Beneath them are two intertwined fiery wheels and two seraphs (Figs. 3 and 8).

Further down, a monumental representation of the Cross, with lance and sponge, within a brilliant mandorla of light, is surrounded by angels (Fig. 9). The inscription reads: "The lifegiving and venerable Cross." On each side is a tetramorph: the four apocalyptic beasts, considered as symbols of the four Evangelists. They are nimbed, which suggests the unity of the four Gospels, a common theme.

It is only in the register next below this that Christ as Judge, surrounded by angels, occupies the central panel. As on the Vatican dalmatic, the text on the large book which he is holding is from Matthew 25: 34. Interceding on each side, are the Mother of God and St. John the Baptist; in other words, it is a large Deesis. Around them are the just: hierarchs on the left and kings and princes on the right (Figs. 3 and 10-14).

Other figures are deployed on the adjoining south and west walls and pillars, including the twelve apostles, the prophets, kings and priests of the Old Testament, bishops, martyrs, military saints, monks, anchorites, nuns and holy women among the just (Fig. 15). ${ }^{26}$ There are panels representing the rising of the dead (Fig. 16), the entrance to Paradise, the gate guarded by the cherub with the fiery sword, and, in a hilly white landscape within the walls of the heavenly Jerusalem, are Abraham on a golden throne, holding the souls of the just in his bosom (Fig. 17), the Good Thief (Fig. 18) and the Virgin Mary, also seated on a golden throne. ${ }^{27}$ On a series of smaller panels one can see the earth and the sea returning the dead, ${ }^{28}$ while two classical figures, the personifications of the Earth $^{29}$ and the Sea (Fig. 19), are represented separately.

[22] In addition we find a scene of the weighing of souls (Fig. 20), as well as scenes of various torments and punishments, including a group of sinners banished to the "outer darkness' (Fig. 21) and

${ }^{26}$ Davidov-Temerinski, "Cycle of the Last Judgment," Fig. 8.

27 Ibid., Fig. 11.

${ }^{28}$ Ibid., Fig. 9.

${ }^{29}$ Ibid., Fig. 5. 
"the worm which sleepeth not." 30 A personified Hades sitting on a monster is calling to sinners to approach. ${ }^{31}$ The Archangel Michael with his sword is pushing the damned deeper into the fiery river, where the rich man, Dives, is already kneeling (Fig. 22). A standing figure of Christ holding a sword is represented in the bottom register. The inscription reads: "With this sword sins will be smitten" (Fig. 23).32

[23] As mentioned earlier, Gabriel Millet and other scholars after him have noted the correspondence between St. Ephraim's (or Pseudo-Ephraim's) writings and this iconography, to which elements from other sources were added, too. One should remember that many of these descriptions were first incorporated in the Liturgy, in this case especially in the Liturgy of the Sunday of the Last Judgment, which is celebrated in the pre-Lenten period. Expressions of Christian awareness, piety, fear, resignation and hope in this Liturgy were subsequently interpreted by the artists, often in a quite remarkable way.

In Millet's opinion, the detail of Christ Emmanuel on the Vatican Dalmatic, on the one hand, and, on the other, of Christ Emmanuel descending in glory at Dechani, accompanied by the luminous Cross, expressing in such a splendid way the idea of the salvation of humanity through Christ's Incarnation, suffering and death, brought these two works of art even closer to the theology of St. Ephraim. 33

For my part, I would like to underline the fact that the contents of St. Ephraim's letter to Publius (which was unknown to Millet) can greatly contribute to that conclusion. ${ }^{34}$ Using one of his favourite metaphors, St. Ephraim recommends to his correspondent to look into the polished mirror of the holy

${ }^{30}$ Davidov-Temerinski, "Cycle of the Last Judgment," Fig. 17.

31 ibid., Fig. 14.

${ }^{32}$ I. G. Passarelli, "Nota su di una raffigurazione del Pantocrator a Decani," OCP XLIV (1978): 181-9.

33 This has been emphasized by Davidov-Temerinski, "Cycle of the Last Judgment," 208, who has also pointed out the proximity of the tomb of King Stefan Uroš III in that context. See also D. Popovic, The Royal Tomb in Medieval Serbia (in Serbian with English summary) (Belgrade, 1992) 109-10.

${ }^{34}$ Brock, "Ephrem's Letter" (see note 21). 
Gospel ${ }^{35}$ and says: "Look at the judge of righteousness ready seated; look at the Word of his Father, at the wisdom of his nature, at the arm of his glory, at the right hand of his mercy, at the ray of his light, at the manifestation of his rest ... and further: the stretcher out of the heavens, the adorner of the luminaries..." 36 Then he continues: "Look then on that divine child, [we have to remember here the picture of Emmanuel on the throne] whose names exceed what creation can count ... calling to his blessed ones, "Come inherit the kingdom - that was prepared for them from of old in his knowledge and was made ready for them from the beginning of creation..." ${ }^{37}$ Enumerating the names of Christ, Ephraim reminds his friend that Christ is the "gate of salvation" and the "way of truth." 38 It is interesting to observe that in the narthex, on the other side of the wall on which the Last Judgment is depicted at Dechani, a large bust of Christ is represented above the main entrance door, leading into the naos. On the open book held by Christ, one reads words from John 10: 9: "I am the door: by me if any man enter in, he shall be saved and shall go in and out and will find pasture." Immediately below, two kings, father and son, founders of the church who commissioned these paintings, are imploring grace and wisdom from Christ, who is the "gate of salvation" and "the way of truth:" a scroll is handed to each of them by the cherub (Fig. 24). Higher up, the Biblical parallel is underlined by the representation of Kings David and Solomon, father and son..$^{39}$

As if to confirm the link, there are depictions of St. Ephraim in the church at Dechani, too: within a monumental Menologion for the whole year which starts with the $1^{\text {st }}$ September, right above this panel, and is deployed clockwise around the whole narthex, thus forming the "crown of the year" (Psalm 64(65): 11), St. Ephraim is represented on the south side, for the day of the $28^{\text {th }}$ January. 40

35 Brock, “Ephrem's Letter," 271-74.

36 Ibid., 278.

37 Ibid., 280.

${ }^{38}$ Ibid., 278.

39 Z. Gavrilovic, "Kingship and Baptism in the Iconography of Decani and Lesnovo," in Decani et l'art byzantin, 297-306.

${ }^{40}$ S. Kesic-Ristic and D. Vojvodic, "Menologion," in Mural painting, 377-434. 
There is also a standing figure of St. Ephraim in the bottom register on the north side, but it is not very well preserved.

From the tremendous fund of imagery transmitted through St. Ephraim's works, artists and their patrons were able to choose and combine details as they found it appropriate. Although the Last Judgment at Dechani is considered a unique case in monumental Byzantine painting, because of the dual representation of Christ's Parousia, we must remember that other examples may contain details from St. Ephraim's writing which are not included at Dechani. For instance, in his letter to Publius, St. Ephraim treats at some length the parable of the Rich man and Lazarus from the Gospel of St. Luke (16: 24) $)^{41}$ which at Dechani is illustrated separately, within the cycle of Christ's parables. The Rich man, Dives, does appear in the scene of Hell (see above), but Lazarus is not identified in the general scene of Abraham's bosom. Similarly, the Parable of the Wise and Foolish Virgins, to which St. Ephraim often refers in his other works, and particularly in the letter to Publius, ${ }^{42}$ is sometimes included in the scene of the Last Judgment; at Dechani, it is represented just outside it, above the throne of the king. ${ }^{43}$ This in itself has a particular significance. In his second kontakion on the Ten Virgins, Romanos the Melode states that this parable is a model for those who govern the people, as it points the road to humility and teaches compassion. ${ }^{44}$

I mentioned a little earlier St. Ephraim's favourite metaphor of the mirror. It so happens that at Dechani, one finds a rather unusual representation of Christ's Descent into Hades, a theme which also holds an important place in St. Ephraim's theology. ${ }^{45}$ A unique detail in the Anastasis at Dechani are the discs held by two angels who are accompanying Christ as he raises Adam and Eve from Hades. Within each of those discs is depicted a bust of a

${ }^{41}$ Brock, "Ephrem's Letter," 275-6.

42 Ibid., 285-6.

${ }^{43}$ M. Radujko, "Fresco Program around the King's Throne," in Mural painting, 305-7.

${ }^{44}$ J. Grosdidier de Matons (ed., Fr. tr.), Romanos, Hymnes III (Sources Chrétiennes 114; 1965) 303-65, esp. 334; cf. Z. Gavrilovic, "Divine Wisdom as part of Byzantine imperial ideology. Research into the artistic interpretations of the theme in Medieval Serbia," Zograf 11 (1980): 44-53.

$45 \mathrm{~J}$. Teixidor, "Le thème de la Descente aux enfers chez Saint Éphrem," L'Orient Syrien 6 (1961): 25-40. 
small figure in royal clothes, wearing a crown (Figs. 25 and 26). In a recent article I have suggested that these discs may represent actual mirrors in which Adam and Eve, freed from the clutches of death, are now able to perceive the future royal status of the saved humanity. ${ }^{46}$ Although I had referred to St. Ephraim's well known predilection for the metaphor of the mirror, with all its poetical qualities and refined spirituality which it contains, I have also mentioned other authors in whose writing the symbolism of the mirror held a prominent part.

However, in Dechani, it looks as though St. Ephraim's influence may have played an even greater part than it has so far been acknowledged. One should bear in mind, for instance, the cycle of Genesis in the fresco-programme of the church, with some unique representations of the tale of Lamech, of Noah and the Flood and of some other Old Testament scenes. ${ }^{47}$ They all found their place in the astonishing wall-painting ensemble at Dechani. One perceives a marked tendency on the part of the patrons and of their theological advisors to express the perfect harmony between the Old Testament and the New, so important in Christian teaching in general and in St. Ephraim's typological theology in particular. ${ }^{48}$

There is no doubt that in Byzantium and in the lands of its sphere of influence the memory of St. Ephraim, an author so profoundly engaged in discovering the marvel of God's creation,

46 Z. Gavrilovic, "Discs held by angels in the Anastasis at Decani," in C. Moss, K. Kiefer (eds.), Byzantine East, Latin West. Art-historical studies in honor of Kurt Weitzmann (Princeton, 1995) 225-30.

47 J. Markovic and M. Markovic, "Genesis Cycle and Old Testament figures in the Chapel of St. Demetrius," in Mural Painting, 323-52; M. Gligorijevic-Maksimovic, "Le Tabernacle à Decani, origine et développement du thème," in Dechani et l'art byzantin, 319-37.

48 A manuscript containing a text attributed to St. Ephraim (Paraenesis) was copied and decorated in 1337 for the first abbot of Dechani, Arsenije (Belgrade, SANU 60). See I. Djordjevic, "La représentation de Stefan Decanski tout près de la cloison du sanctuaire à Decani," Saopstenja 15 (1983): 35-43, with earlier bibliography. Among other preserved works by St. Ephraim (or attributed to him) in Serbian literary tradition, one should mention a manuscript dating from the $15^{\text {th }}$ $16^{\text {th }}$ centuries (Belgrade, SANU 146), containing a sermon on the Coming of the Lord and the Judgment. See S. Radojcic, "Mileševske Freske Strašnog Suda," Glas SAN CCXXXIV/7 (1959): 69-79. 
made a great impact on artists and on all those responsible for providing a milieu for artistic expression. St. Ephraim was known as "the Harp of the Holy Spirit," and he himself refers to the three "harps" on which God plays, those of the Old Testament and the New, and that of the Creation. ${ }^{49}$ Over the centuries, all aspects of his theology, including his thoughts on Christian Baptism and the Mother of God, were certainly absorbed into the complex system of Byzantine art: the field of research is still wide open. ${ }^{50}$

The affection and respect for St. Ephraim are manifested also in the representation of his death and funeral, a theme which became popular in wall-painting and on icons in the post-Byzantine period (Fig. 27). I touched on this at the beginning of this article. The scene is set in a landscape within which one recognizes hermits writing or meditating in their caves; monks are busy carving spoons or weaving baskets. In the centre of the picture St. Ephraim's body is surrounded by clergy and monks (some of them infirm), who have come to pay their respects. This monk or that is riding on the back of a bear or a lion, as the paradisiacal atmosphere of the occasion has made the wild animals tame. (In Hymns on Faith 21-3 Ephraim compared the lyre on which Christ plays implicitly to that of Orpheus, who tamed the wild beasts with his music.) According to monastic practice, a monk is sounding a wooden board, or semantron (a substitute for a bell, used in Orthodox monasteries in preference to bells). There is usually a pillar-saint in the background and one finds charming representations of small animals, birds and plants, reminiscent of the poet's close observation of "the small things' of nature by which the Creator "baffles the wise." 51

49 Hymns on Virginity, 28, 29 and 30. See Ephrem the Syrian, Hymns, transl. and introd. by K.E. McVey (New York/Mahwah, 1989) 385-97. R. Murray, art. cit., 222.

50 For instance, an interesting suggestion for a connection between the fifteenth Hymn of the Nativity (recording included in this issue) and the depiction of Mary as Hodegetria, is made by A. Palmer, "A Lyre Without a Voice:' The Poetics and the Politics of Ephrem the Syrian," ARAM 5 (1993): 371-99.

51 J. R. Martin, “The 'Death of Ephrem' in Byzantine and early Italian Painting," Art Bulletin 33 (Dec. 1951): 217-25. 


\section{LIST OF ILLUSTRATIONS}

Fig. 1: St. Ephrem.

Church of St. Nicholas, Psacha.

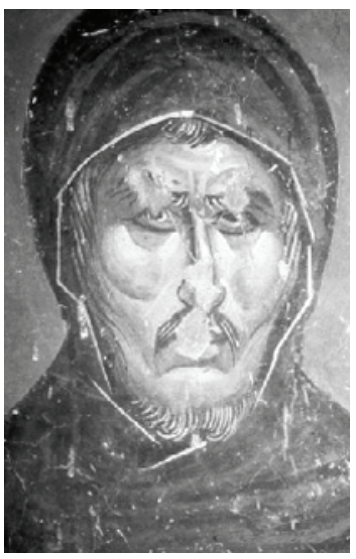

Fig. 2: Dechani, View.

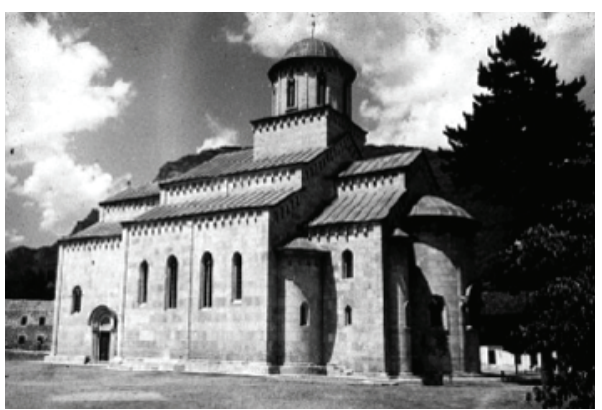


Fig. 3: Dechani, Naos, West Wall. General View.

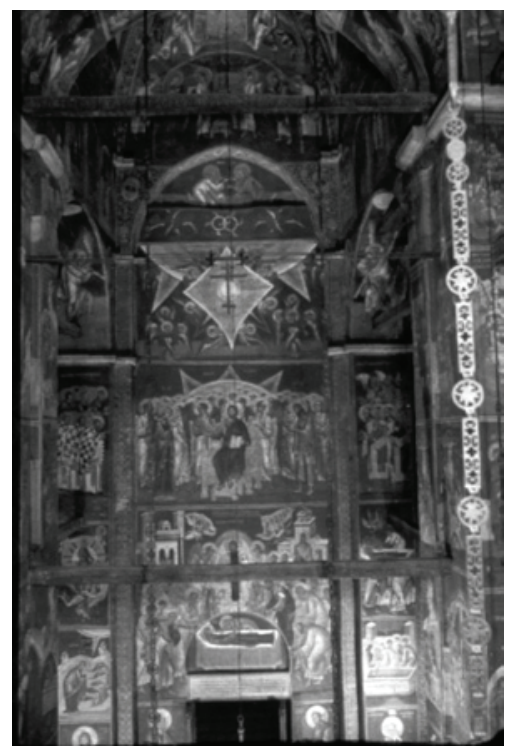

Fig. 4: Dechani, Last Judgment.

Angels with Candles and the Personification of the Sun.

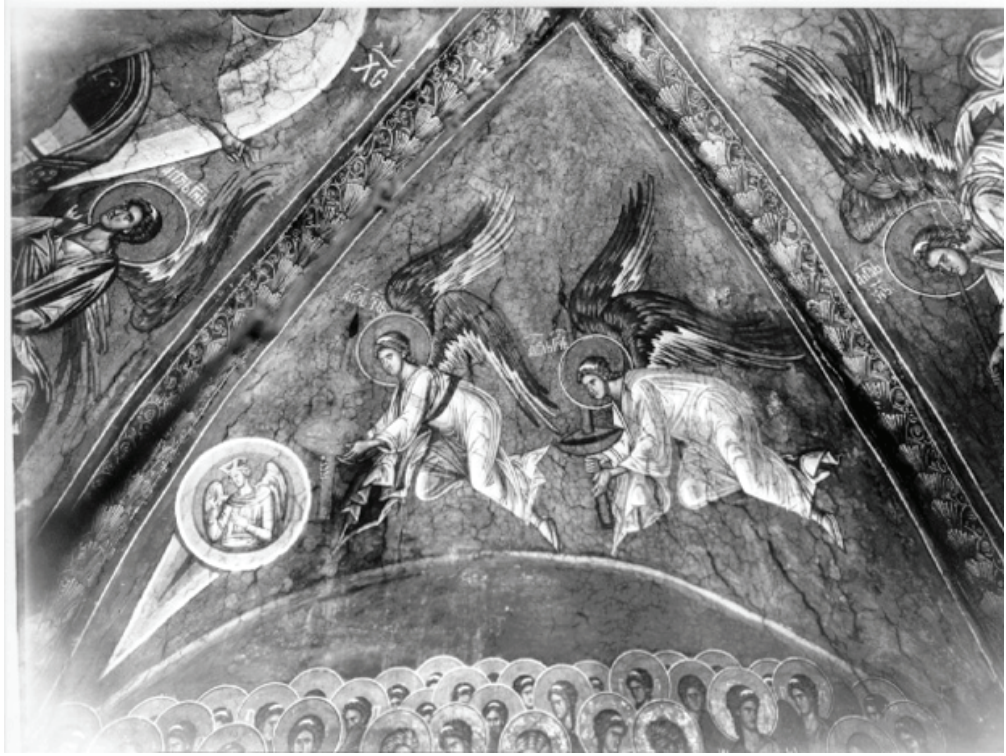


Fig. 5: Dechani, Last Judgment.

Angels Rolling up the Heavens and the Personification of the Moon.

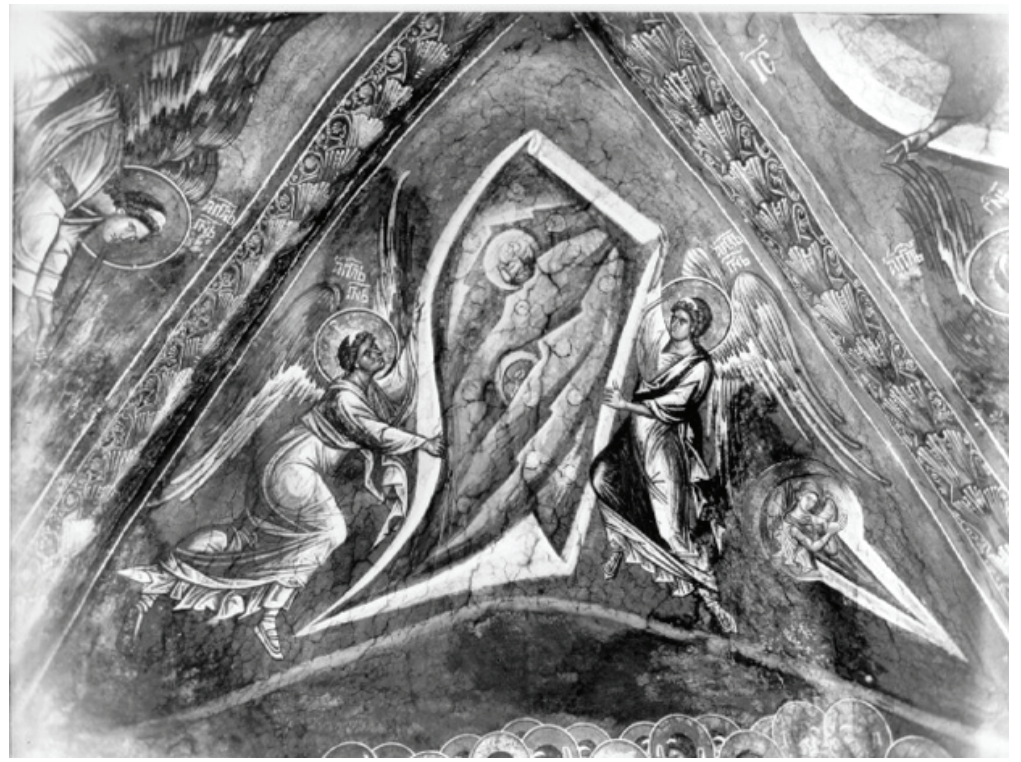

Fig. 6: Dechani, Last Judgment. Emmanuel on the Throne.

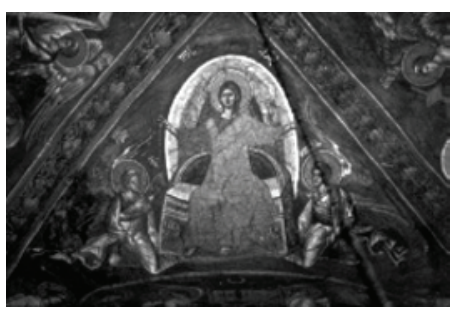


Fig. 7: Dechani, Last Judgment.

Emmanuel on the Throne and Hetoimasia.

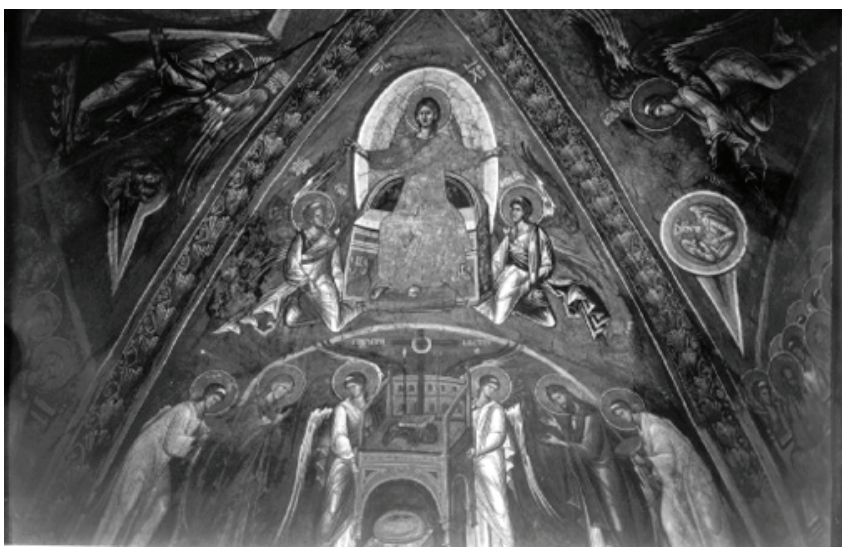

Fig. 8: Dechani, Last Judgment.

Adam and Eve.

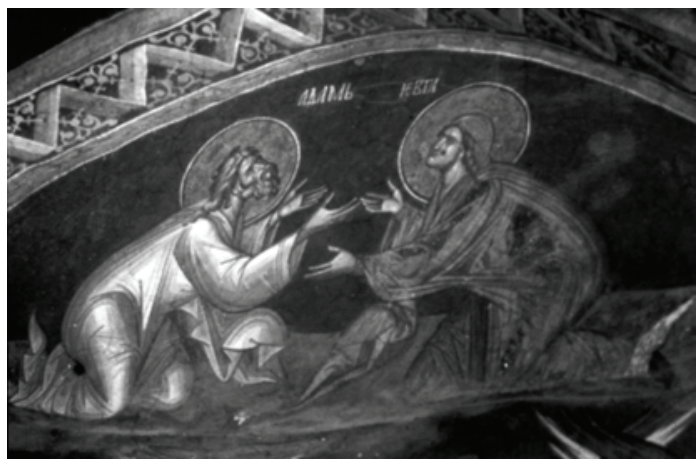


Fig. 9: Dechani, Last Judgment.

The Luminous Cross.

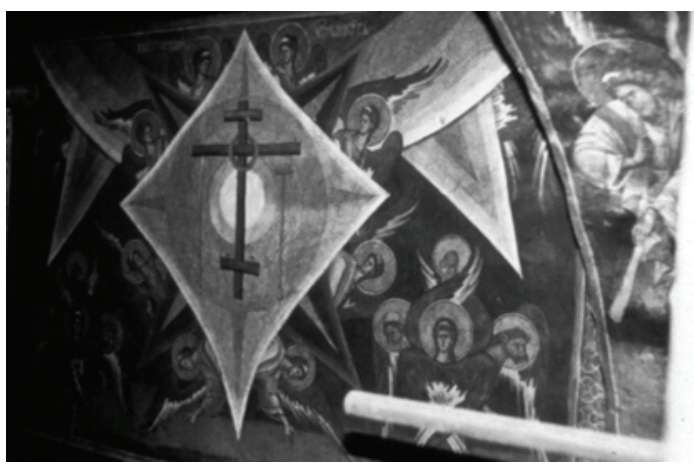

Fig. 10: Dechani, Last Judgment. Central Panel.

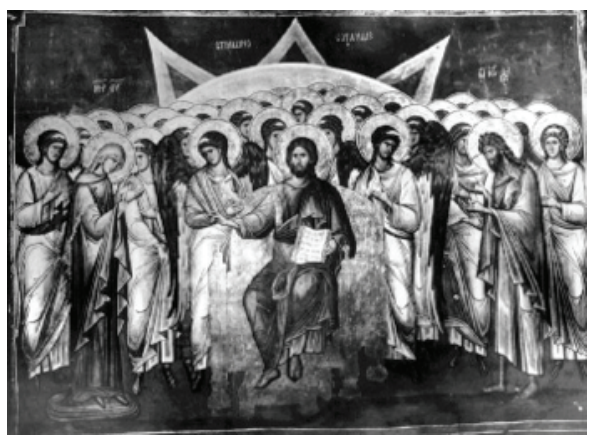


Fig. 11: Dechani, Last Judgment.

Christ the Judge with Kings and Princes.

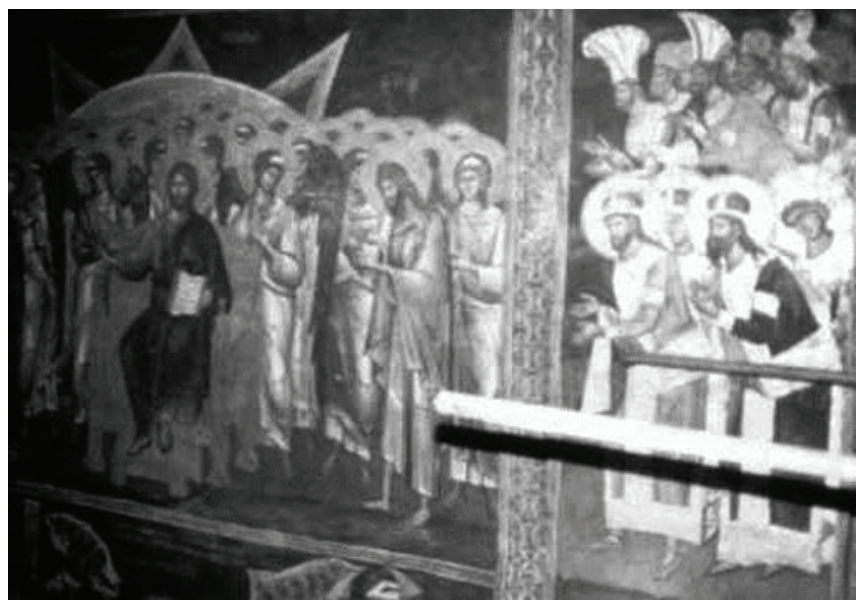

Fig. 12: Dechani, Last Judgment.

St. John the Baptist.

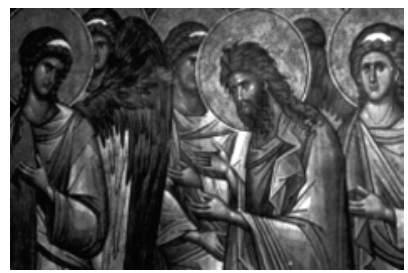

Fig. 13: Dechani, Last Judgment.

Kings.

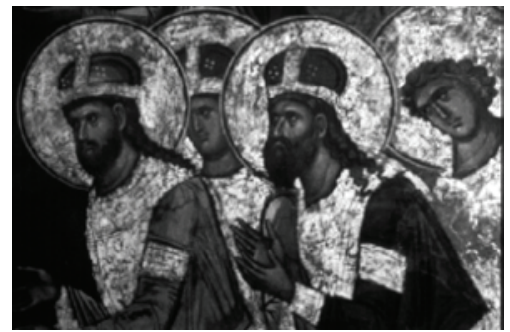


Fig. 14: Dechani, Last Judgment. Princes.

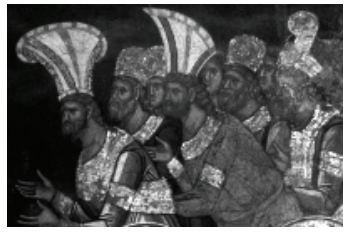

Fig. 15: Dechani, Last Judgment. Apostles and Holy Women.

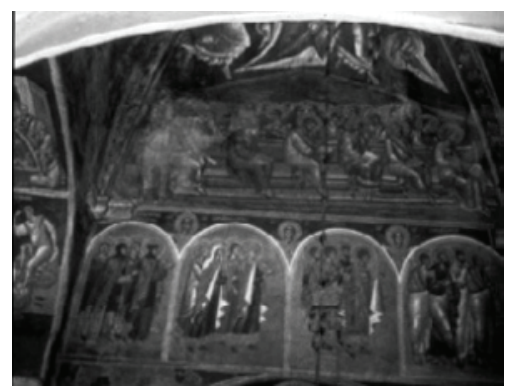

Fig. 16: Dechani, Last Judgment. Raising of the Dead.

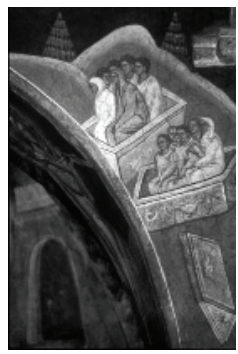


Fig. 17: Dechani, Last Judgment. Abraham's Bosom.

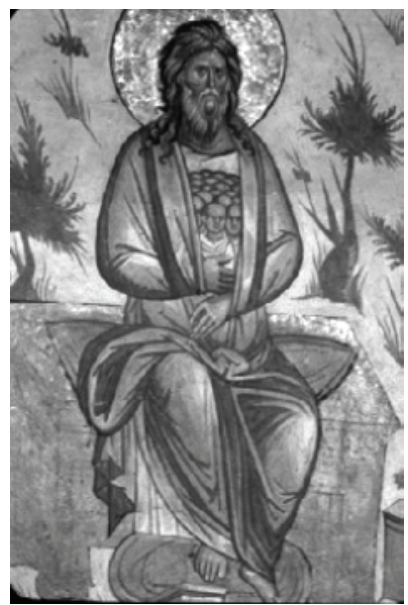

Fig. 18: Dechani, Last Judgment. The Good Thief.

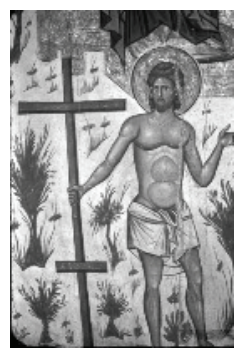


Fig. 19: Dechani, Last Judgment. The Personification of the Sea.

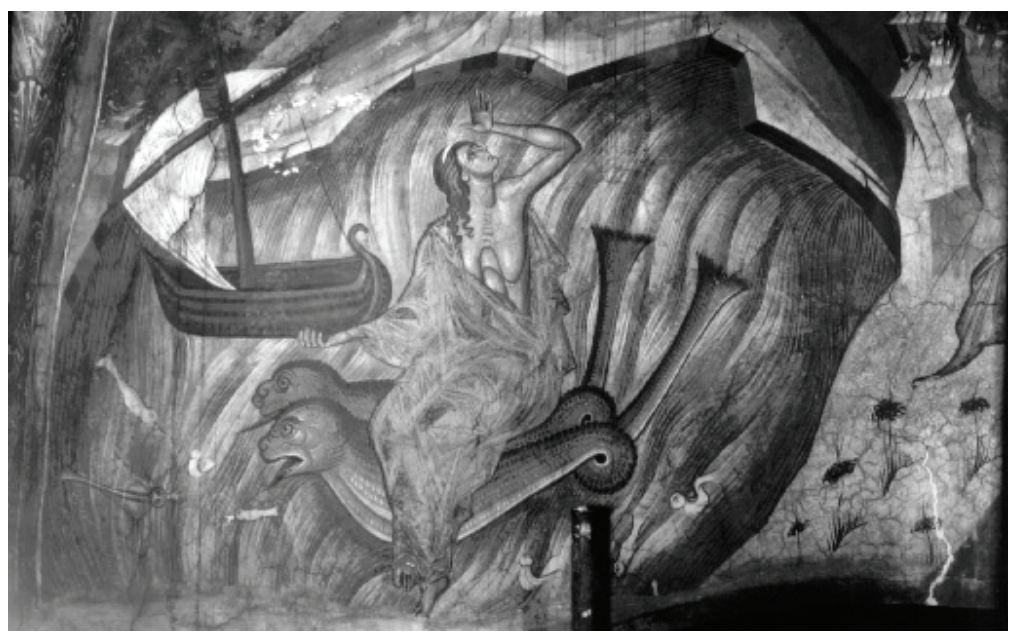

Fig. 20: Dechani, Last Judgment. The weighing of Souls.

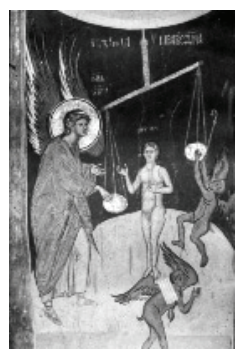

Fig. 21: Dechani, Last Judgment. The Outer Darkness.

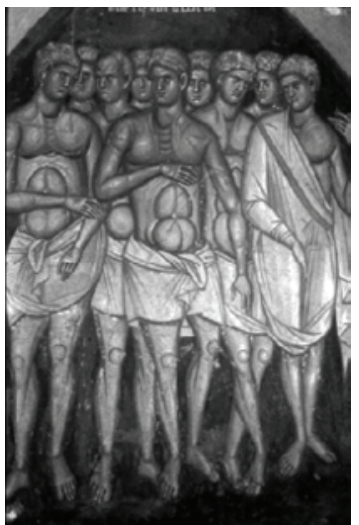


Fig. 22: Dechani, Last Judgment. Archangel Michael and the Fiery River.

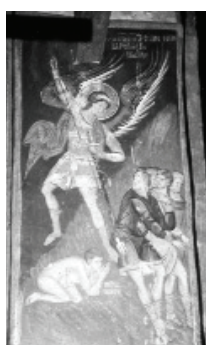

Fig. 23: Dechani, naos.

View of the South-Western Pillar with Scenes of the Last Judgment and Christ holding the Sword.

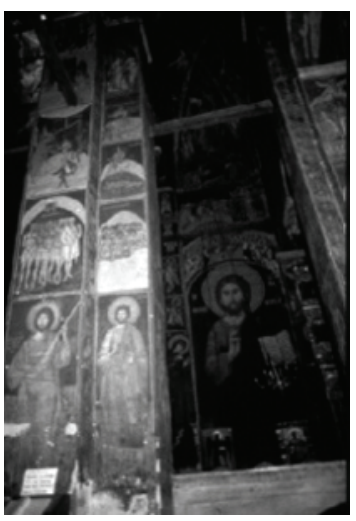

Fig. 24: Dechani, Narthex, East Wall. Christ Pantokrator and Two Royal Founders.

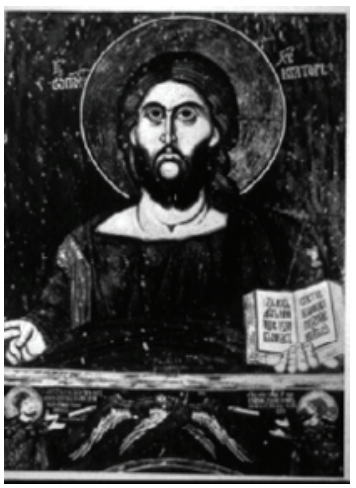


Fig. 25: Dechani, Naos. Anastasis.

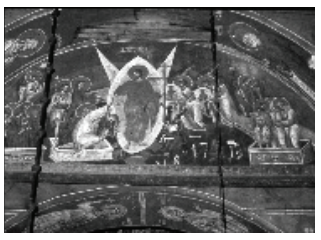

Fig. 26 Dechani, Naos. Anastasis, Detail.

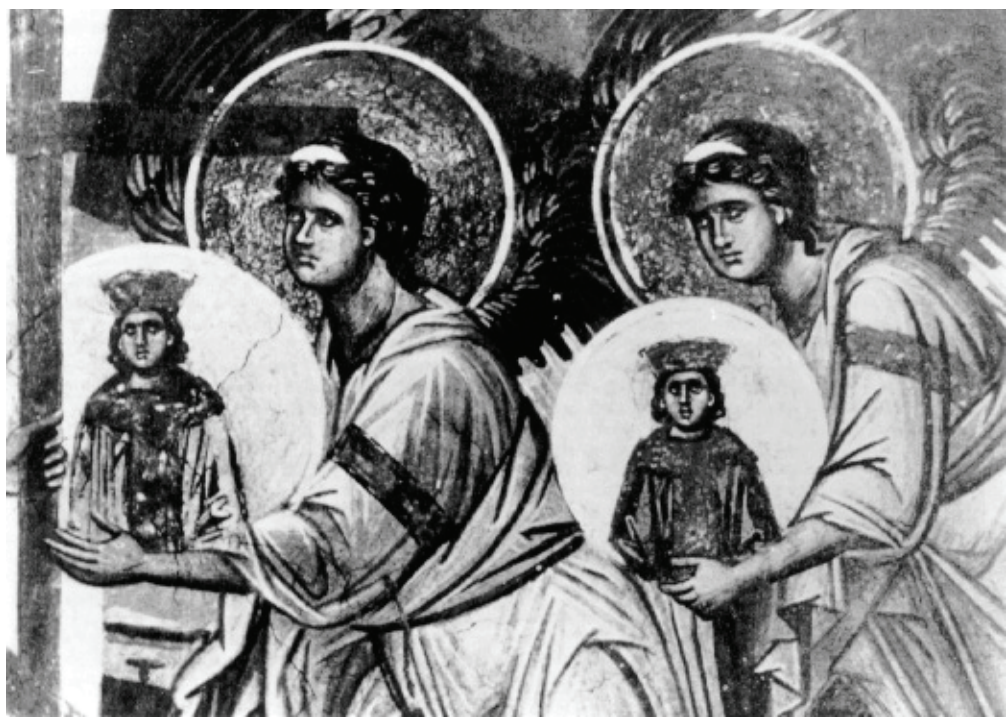

Fig. 27 Monastery of Iviron, Mount Athos, Icon:

Death and Funeral of St. Ephraim the Syrian (15th century)

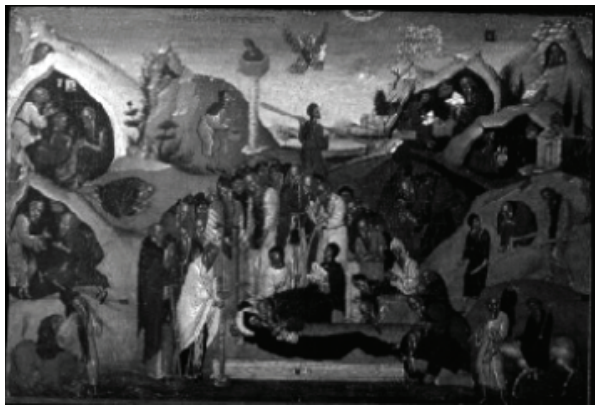


